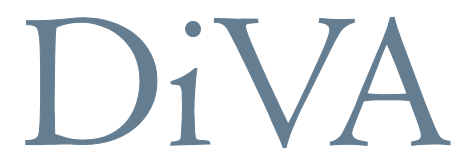

http://uu.diva-portal.org

This is an author produced version of a paper published in Critical Perspectives on Accounting. This paper has been peer-reviewed but does not include the final publisher proof-corrections or journal pagination.

Citation for the published paper:

Bay, C. (2011) Framing financial responsibility: an analysis of the limitations of accounting. Critical Perspectives on Accounting, 22:6, 593-607.

http://dx.doi.org/10.1016/j.cpa.2011.03.001

Access to the published version may require subscription. 
Published in

Critical Perspectives on Accounting

2011, Vol. 22, No. 6, p. 593-607

\title{
Framing Financial Responsibility: An analysis of the limitations of accounting
}

\author{
Charlotta Bay \\ Uppsala University, Sweden
}

\begin{abstract}
In organisations, a ccounting - understood broadly as calculative practices - i s claimed to serv e as a critical $v$ ehicle wh en in troducing form s o f in dividual fin ancial resp onsibility. Whereas most prior accounting research has been preoccupied with asserting this claim, this paper opens a $n$ opportunity $t$ o exam ine $t$ he limitations of acc ounting a $s$ a $t$ echnology o $f$ responsibilisation. It does so by moving the empirical focus beyond the borders of people's work settings and into the private sphere of everyday life, investigating governmental efforts to turn high school stud ents in to fin ancially resp onsible citizen $\mathrm{s}$. The analysis, in formed by fram ing th eory, reveals th at the efficien cy of accoun ting i s co nditioned by p eople's calcu lative un derstanding. Hence, in situations where individuals are ex pected to lack this basic calculative c ompetency, accounting is presumed to be inappropriate as a means of introducing financial responsibility. This has implications for re-con sidering ho $\mathrm{w}$ the relatio $\mathrm{n} \mathrm{b}$ etween accounting and resp onsibility is constituted.
\end{abstract}

Keywords: accounting limitations; responsibilisation; financial education; private sphere; choicemaking discourse; framing analysis 


\section{Introduction}

How does one turn people into financia lly responsible citizens? This is a question that for the past decade has been of great international concern (OECD, 2005, 2006, 2008). In fact, higher levels of credit card debt, over-consu mption and ignorant investm ent strategies have $\mathrm{m}$ ade governm ents all over th e world seriously alar med by their citizens , inability to proper ly c are $f$ or the ir own private $f$ inances. However, the ch allenge of influencing people's habits and a ttitudes with $\mathrm{r}$ egard to $\mathrm{f}$ inancial $\mathrm{r}$ esponsibility is complex because ind ividuals do not walk in to this role ready $m$ ade. Instead - to draw on Hacking (1986) - the role of a financially responsible person quite literally needs to be " made up". In order to becom e som eone who knows how to make sound, calculable decisions, and who appreciates the opportunity to be self-sufficien $t$, people $m$ ust be given the $m$ eans, tools and motives for becom ing just that. They $\mathrm{m}$ ust go through a transfor mation in which they are taught how to think, act and appreciate life acc ording to financial term s. Hence, to $\mathrm{m}$ ake sense in people's everyday life, financial responsibility needs to be framed accordingly.

The activities used in order to make people financially responsible have been of major interest to accounting researchers. Or to be exact, the activities in people's workplaces, that is. Decades of intense investigation (e.g. Roberts and Scapens, 1985; Miller, 1994 ; Sinclair, 1995; Miller, 2001; Kurunmäki, 2004) proves that in order to encourage and support individual responsibility within people's professional practices, different kinds of accounting systems, audit procedures and perform ance m easurements play a cr itical constitu tive role. Since accou nting practices are con sidered to spur certain hum an capabilities that prom ote rational decision-making and responsible econo mic actions in people (Miller and O'Leary, 1990), they owe the potential to "transform a 11 individuals, whethe $r$ they be managers, workers, doctors, or teachers, into calculati ng selves" (Miller, 1994: 247). This indicates a close relationship between accounting and indi vidual responsibilisatio $n$. Hence, the point made is that engaging people in calculation makes them responsible.

Nevertheless, to engage in accounti ng practices presupposes that people can read "accounting-scribbles" (Kirk and Mouritsen, 1996: 257). This is an ability that does not solely depend on the availability of technical devices, but that people indeed recognise accounting as a useful $\mathrm{m}$ eans to support financ ial decision-making. Presumably though, that is not som ething that people know by heart. Just as children need to discover the logic of 
letters before being able to read, people need to be made aware of the logic of accounts before being ab le to calculate. It coul $d$ th erefore $b$ e argued that in order for people to engage in calculative practices, they $\mathrm{m}$ ust first be e quipped with calculative literacy. Hence, th e efficiency of accounting as a means of re sponsibilisation is pre-conditioned by the individual's calculative understanding, which not only enab les him to m ake use of accounts as tools for reach ing a given end, but also to acknowledge them as such. In peop le's workrelated practices, this condition seems to be either already achieved or taken as a given.

However, there is $m$ ore to life than work. And to accounting as well. Besides affecting the ways of doing things at work, it is argued that accounting also inte rvenes and transforms hum an behaviour in areas it was previously excluded (Power, 1992; Hopwood, 1994; Miller, 2007). Even so, m arginal efforts have been made to investigate those activities aimed at influencing the $\mathrm{m}$ ore mundane everyday financial activities taking place ou tside of people's workplaces (see e.g. Llew ellyn an d Walker, 2000; W alker, 2003; Carnegie and Walker, 2007; Johed, 2007; Jeacle, 2009). As opposed to $\mathrm{m}$ ost accounting researchers "preferring to seek solace in the sphere of the corporation rather th an the coffee shop" (Jeacle, 2010), this paper refocuses the empirical scene away from people's work settings and into th eir $\mathrm{p}$ rivate sphe res. By contrast to th e organisa tional ar ena, th is is a $\mathrm{f}$ ield partly inhabited b y individu als unaccus tomed or $\mathrm{w}$ ith lim ited experien ce of financial concerns, lacking tho se calcu lative capacities, skills a nd pre-understandings that seem to be predetermined in the organisational real $\mathrm{m}$. Given this lack, the paper asks: How are nonprofessional people with limited financial experience made to take responsibility for their own personal finances?

The aim of this pap er is to prob lematise the ass umption that accoun ting is of key im portance when introducing refor ms coupled with individual financial responsibility. Whereas most accounting studies on organisational behaviour are preoccupied with asserting this function, this paper opens an opportunity to consider the limitations of accounting as a technology of responsibilisation. It does so by shifting the contextual setting, examining how young individuals are encouraged to think of themselves as financially responsible in situations related to their own everyday lif e. The paper describes the activities of a Swedish high school project conducted by public authoriti es in 2008. The project form s part of a government initiated financial education prog ramme that aim s to improve the citizens' financial capability. The case offers an analysis of how to understand what the authorities are saying and doing in the classroom, where the idea of fina ncial responsibility is introduced to 
students. Given the shift of e mpirical focus, this paper offers a point of departure for (re)considering the preconditions that constitu te accounting as a technology of responsibilisation.

It is im portant to note that the intention of this paper is not to determ ine whether in $\mathrm{f}$ act the $\mathrm{h}$ igh school stud ents became financially capable, o $\mathrm{r}$ even affected their perception of financial responsibil ity. Rather than looking for e ffects, the study is prim arily concerned with investig ating the authorities' presumptions of how to turn young, financially inexperienced individuals into financially $r$ esponsible citiz ens. In o rder to exam ine these assumptions, the paper offers a fra ming analys is (Benford and Snow, 2000) of a) how the authorities chose to conceptualise the idea of financial responsibility, and b) by which means this idea was communicated to high school students in their cla ssroom settings. Of particular interest is to learn whether or not calculative devices were included among those means used for affecting the students' view on financial responsibility.

The outline of this paper begins by detailing the backdrop of the empirical case, positioning the Swedish financial educatio $\mathrm{n}$ programm e in line with corresponding international developments. The subsequent Se ction 3 describes fram ing analysis (Benford and Snow 2000), which is used to analyse the empirical case. Thereafter, in Section 4, the design of the study is described; in other words, the efforts that have been carried out in order to collect and classify the data. In Section 5, the empirical findings are reported and analysed, and divided into three subs ections (see 5.1, 5.2, 5.3), followed by a discussion in Section 6. In the final part of the paper, Section 7, conc lusions and contributions of the paper's findings are summarised.

\section{Backdrop}

During the autum $\mathrm{n}$ of 2008 , a court of pub lic authority representatives visited thousands of high school stude nts across Sweden. Their goal was to encourage high school teachers to m ake personal financ ial management an integ ral part of the students ' mandatory subjects by giving an on-site dem onstration of how this $m$ ight be done. At an offi cial high school visit, the Swedish Minister for Financial Markets confidently declared: 
It is vital that school provides financial education. To say the least, to learn how to go about buying an apartment is just as important as to learn the year of Charles XII's death. ${ }^{1}$ (Odell, 2008)

The high school tour, which com prised of 24 locations and 4,000 students, was carried out by a group of prom inent public authorities: the Fi nancial S upervisory Authority (FSA), the Enforcement Authority (EA) and the Consum er Agency (CA). It targeted students at a stage in life when $m$ any move away from home to start a household of their own. At the schools, the public authority representatives introduced a teaching package describing what to think about when starting up a life for oneself and an on-site dem onstration of how the teaching material may be used in class. Accord ing to the tour organisers, "the general goal is to get young people to reflect upon the choices th ey make" in order to em power students to "make financially wise decisions in the future" (Finansinspektionen et al., 2008).

The tour did not pass by unnoticed. Nati onal Swedish Radio covered the issue (Plånboken, 2008), along with severa 1 of the major morning papers in S weden (e.g., Svenska Dagbladet, 2008; Sydsvenska Dagbladet, 2007) . . And at alm ost every stop, the local newspaper was reporting on the events. According to the organisers, the reactions amongst the teachers at the tour sites were mainly positive and sometimes even overwhelming:

It's so great that you are here because this is more important than learning about history.

The high school tour is one project among others (see Finansinspektionen, 2007b), forming part of the Swe dish government initiated Financial Education Programme (Finansiell Folkbildning) launched earlier that same year. The programme is coordinated by the Financial Supervisory Authority and s upported by a num ber of public authorities and financial organisations. Its general goal is to "strengthe $\mathrm{n}$ financial consumers by means of information and financial education" (governm ent letter of regulation for the FSA, 2008, Goal 3). The programme aim s at edu cating Swedish c itizens to b ecome financially capab le, ultim ately producing people who know how to make sound, calculable decisions, and who appreciate the opportunity to become responsible for oneself (Finansmarknadsrådet, 2007a).

The initiation of the financial educa tion programme needs to be understood in relation to changing econom ic and political de mands. For example, the new Swedish public pension system, which cam e into effect in 199 9, involves a considerable shift away from

\footnotetext{
${ }^{1}$ Swedish king (1682-1718)
} 
collective provision towards individualise d responsibility (Lundberg, 2003; Johed, 2007; Ohlsson 2007; Belfrage, 2008). As individual financial investm ent underpins the welfare of people's everyday lives now more than ever (such as housing, studies, pensions, daycare, and health), the expecta tion of th eir capacity to behave as risk-tak ing investo rs and active decision-makers intensifies (Harmes, 2001; Greenfield and Williams, 2007; Langley, 2007). Cultural and political econom ists (e.g. Erturk et al., 2007; W illiams, 2007; Langley, 2008; Finlayson, 2009) conclude that the financialisation of people's daily lives (Martin, 2002) and the increasing reliance on the capital market as a major welfare provider has radically altered the conditions of how to run one's own financial affairs.

However, the daily use of credit cards and the constant concern for house mortgages along with a num ber of welfare ref orms asking people to increasingly rely on individual market investments have had profound, and at times devastating, consequences for moderate income households. Eighteen per cent of Swedish adults claim they have problem s paying their bills, and almost half a million people are regis tered as indebted (Kronofogden and Konsumentverket, 2008: 6). And beyond the Sw edish borders it gets even worse. In fact, ever increasing levels of financially distressed consumers, over-indebtedness ${ }^{2}$ and personal bankruptcies (OECD, 2005: 62-64) have driven governments all over the world to qu estion their citizen s' com petency for $\mathrm{m}$ anaging their own $\mathrm{m}$ oney. The intern ational reactions to these signals are referred to as a "quiet pa nic" (Froud et al., 2007): the OECD portrays this inability as financial illiteracy and warns that if measures are not taken, a substan tial amount of people will end up in financial isolation (OECD, 2005).

The measure of initiating a financial edu cation programme in order to $\mathrm{m}$ eet these new dem ands is not exclusive to $S$ weden. In fact it is quite the oppo site: during the past decade, ind ividual coun tries, as well as the $\mathrm{OE} \mathrm{CD}$ and the EU, have all ag reed to financial education plans ${ }^{3}$. In addition, the issue has also br ought about a considerable amount of national advisory groups and coordination units such as the Canadian Task Force on Financial Literacy and the Australian Financial Liter acy Foundation; an abunda nce of sub-programmes including the Am erican Jum p\$tart for Persona 1 Financial Lite racy and the Australia $n$

\footnotetext{
${ }^{2}$ Used to describe a situation when debt or debt service payments relative to income become a major burden for the borrower (OECD, 2005: 63).

${ }^{3}$ The British Building Financial Capability in the UK (Financial Services Authorities, 2003), the American Taking Ownership of the Future: the National Strategy of Financial Literacy (U.S. Department of the Treasury, 2006), and the OECD's Project on Financial Education (OECD, 2009) are only but a few examples of these programmes. For detailed country information, see the OECD website http://www.financial-education.org.
} 
Understanding Money; and inform ation webs ites lik e th e EU Dolceta Onlin e Consum er Education and the OECD Intern ational Gateway for Financial Education. Hence, the issue of how to tackle the financial shortcom ings of the modern citizen has grown into a worldwide concern, which was emphasised in a speech by the Internal and Services Comm issioner Charlie McCreevy at the European Union conf erence 'Bette $r$ financial edu cation for EU consumers':

Those Member States that decide to take consumer financial education really seriously-from classroom to grave-will be the ones that carve out a real competitive advantage in the medium term. These policies are not add-ons. They are essential. (Finansmarknadsrådet, 2006: 10)

The Swedish high school tour is thus to be co nsidered in the light of a global policy tendency in which count ries and international organi sations share the sam e ai m: equipping citizens with a greater responsibility for their financial affairs, which is hoped to eventually strengthen them to take a $\mathrm{m}$ ore active and conf ident role as financial consumers (Financial Services Authorities, 2003).

\section{Theoretical Frame}

This paper is concerned with how Swed ish public autho rities chose to frame their idea of financial responsibility in order to influence high school students' attitude toward financial matters. The task of inducing others to understand and do things according to certain terms is an intricate one, because ideas are not ju st out there, ready to be instantly con sumed, applied and acted upon by people in general (S ahlin-Andersson and Engwall, 2002). Nor are ideas accepted and successfully im itated b ecause they are brillian $t$ in them selves (Røvik, 2002), or ev en because they hold in herent properties that naturally appeal to people's inn er desires. In fact, "hum an desire is something which is ultimately directionless, a mere force, a potential for action and $\mathrm{m}$ ovement, [but] dir ection $\mathrm{m}$ ust be given to it through learning, through being taught" (Howe, 1994: 4). This suggests that what makes the idea of financial responsibility credible is a consequence of how it is presented, casted and rhetorically constructed. Hence, it is in need of being actively shaped and transformed in order to $\mathrm{f}$ it the specific high school setting in which it is intended to operate.

Although everyone $m$ ay be considered to be co-participants in translating new ideas into their own loc al con texts (Latour, 1986), there are those who have chosen as their professional task to deal with translations (for others) in a m ore general sense. Those people 
and their signifying activities are the focus of this paper. They $\mathrm{m}$ ight be understood as merchants of m eaning (Czarniawska-Joerges, 1990), a kind of tr avelling salesmen with their attaché cases full of objects aimed at helping people ascribe new meanings to ideas when they are introduced into local settings. Th ose signifying agents (Snow and Be nford, 1988) act like mediators of new ideas by packaging, shaping and translating their fundam entals so as to be understood and acted upon by their intended receive rs. Of specific significance for this paper are those agents who are portrayed as neutral $\mathrm{m} \quad$ ediators such as the public au thorities presented in the case, who are generally $\mathrm{s}$ aid to $\mathrm{m}$ erely repor $\mathrm{t}, \mathrm{m}$ ediate and inf orm. Nevertheless, as their function ra ther often is to "discuss, interpret, advise, suggest, codify" (Meyer, 1996: 244), they hold quite an influential part in the production of meaning, affecting how people think and act in specific situations.

One way of investigating how the notion of financial re sponsibility is discussed and interpreted by Swedish public authorities in order to be communicated and adopted by high school students is to study the authorities' framing activities. Framing is here understood as "a process whereby communicators, consciously or unconsciously, act to construct a point of view that encourages the facts of a given situation to be interpreted by others in a particular manner" (Kuypers, 2006: 8). This particular point of view, or fram e, operates as an “organizing principle" (van Gorp, 2001: 5) that helps people render the com plex situation meaningful and com prehensible, suggesting what is at issue and how to understand it. As such, constructing frames aspires to steer interpretation and guide action.

The concept of frame is not a recent one. It was in itially introduced by Erving Goffman as denoting a defining means, a "schemata of interpretation" (1974:21) that enables and regulates the way individuals establish meaning of what is going on around them. Ove $r$ the years, the analysis of frames and kindred processes has developed into a multi-disciplinary method, analytically applied and em pirically explored in a variety of $\mathrm{w}$ ays in a diversity of research areas: cogn itive psychology (Tvers ky and Kahnem an, 1981); political science an d policy analysis (e.g., Ga mson, 1988; Schön a nd Rein, 1994); communication and m edia studies (Entman, 1991; Kuypers, 2006); and social movement studies (Snow et al., 1986). In the audit/accounting lite rature, Goffman's concepts of fr aming and keying (1974) have been used for analysing the use of num bers (Vollmer, 2007), and Callon's twin notions of fra ming and overflowing (1998) are em ployed in studies of corporate strategy (e.g., Skærbæk and Tryggestad, 2010), reporting practices (Christens en and Skaerbaek, 2007), and audit failures (Carrington, 2007). 
As opposed to the fram ing analyses inform ed by Goffm an and Callon, which also include how meaning is rem oulded and refo rmulated in (face-to-face) interac tions and through continuous negotiations between different parties (Goffman, 1974; Callon, 1998), the task of this paper is not to determ ine whether the students actually resisted the authorities ' idea or if they em braced it as a whole, or any other response in between. Instead, this paper takes a strict sense-giving perspective (Gioia and Chittiped di, 1991), isolating the efforts of one party (the public authorities) to affect another (the student s). Hence, the fram ing analysis here is used as a m ode to exam ine "the pro cess of attempting to influence the sens e-making and m eaning construction of others toward a pr eferred definition or organisational reality" (Gioia and Chittip eddi, 1991: 442), without taking into consideration whether this process was successful or not.

This paper $\mathrm{m}$ oves fr om how govern ment pronouncements of fi nancial responsibility are refined by public authorities, and finally transform s into stories and activities assum ed to suit the sp ecific local setting of high sc hool individuals. In order to follow this process, we need an an alysis model that simultaneously captures the $\mathrm{d}$ iscursive origins of the idea - of the hows and whys it cam e about — and the means by which this idea is introduced to "become part of the lives of ordinary people" (H acking, 2004: 278). Hence, we need a theoretical fram ework that tak es into accou nt both ho w people's financial behaviour initially is talked about and set out as a problem, and how its proposed solutions are made to work, em bedded as concrete practices in the local high school environm ent. The framing analysis model, as drawn up by Snow et al. (1986), Snow and Benford (1988) and Benford and Snow (2000), offers just that.

To build a frame is to come up with "a normative-prescriptive story that sets out a (...) problem and a course of action to be take $n$ to address the problem atic situation" (Rein and Laws, 1999: 33). The story gives an expl anatory, narrative account of some phenomenon in such a way as to show what is wrong and what needs fixing. In composing such a story, the framing activities $\mathrm{m}$ ust be orien ted toward addressing three elem entary ques tions, each corresponding to what Benford and Snow $(1988,2000)$ call core framing tasks. These concern a) the problem of a specific situation, b) how it is to be resolved, and c) the reasons for people to take corrective action. In the remaining part of this section, the three tasks are given a short elaboration. 
Most problem solving activities are con cerned with seeking solutions (Schön, 1979), where the problems themselves are generally assumed to be already given. However, if an issu e is said to require a so lution, it is because som ething in it in itially appeared problematic to som eone. This suggests that pr oblems are not predeterm ined but constructed by hum an beings. Consequently, the first core framing task has a diagnostic character that simply asks "What is the problem ?" In this process of diagnostic framing, the attention is directed towards articulating the symptoms of a problem atic situation. The analysis of such a process is concerned with id entifying the precise points when a particular issue, situation or behaviour is questioned and $\mathrm{m}$ ade to appear in need of chan ge. Here the sources of causality must be $m$ apped out: dam age m ust be defined, scapegoats singled out and victims put on display. Hence, the assignment of blame and responsibility constitutes a critical component in the analysis of diagnostic framing (Benford and Snow, 2000).

The ways in which problem s are set m ost commonly determine the direction in which solutions should be sought (Schön, 1979). Hence, the second core framing task entails making a prognosis and addressing the question of "What is the remedy?" The analysis of the prognostic framing involves not only an exam ination of "the articulati on of a proposed solution to the problem" (Benford and Snow, 2000: 616), but also of the strategies, tactics and targets that will $\mathrm{m}$ ake the so lution happen. Together, the diagnos tic/prognostic fram ings constitute the discu rsive articu lations of an agenda or a programm e, addressing issues of "responsibility for a situation, th e intervention s that are acceptab le or possible, and what should be done about the problematic situation" (Gamson 1995 in Fisher, 2003: 144).

As fram es help people $\mathrm{m}$ ake sense of a com plex reality-telling them what is right and what is wrong, true and false, good a nd bad-they also provide guideposts directing their future actions. However, the very fact that people understand causes and solutions to a particular problem si milarly does not autom atically produ ce correctiv e action or even any action at a ll. The th ird framing task then is concerned with mobilising motivational impetus for action, asking, "W hy should pe ople bother?" In the process of motivational framing, the story makes "the normative leap from data to recommendations, from fact to values, from 'is' to 'ought"' (Schön and Rein, 1994: 26). The motivational analysis is concerned with how the discursive idea is communicated to its inte nded audience, and how this connection is materialised into words, signs, pictures, and activities that might work as pedagogical motives for taking action. Mobilisation is thus claim ed to be contin gent upon the developm ent of a 
vocabulary of motives, arguments and incentives that function as a rationale for engagem ent, "moving people from the balcony to the barricades" (Benford and Snow, 2000: 615).

According to Benford and Snow (2000), the key to understanding the evolution of frames resides in the articulation processes rather than in the topic $\mathrm{s}$ or issues co mprising the frames. This im plies that it is just as important to find out what the public authorities depict as being the problem, the solution and the reason for action as it is how they choose to bind these three elem ents togeth er. It conc erns how these pieces are assem bled, how the arguments are organised, and how c onnections are established when linking the problem of financial illiteracy to the solu tion of financial education, fo llowed by a particular kind of action to be taken. It is through these relatio ns and liaisons that a frame grows strong and persuasive.

To sum up, the fra ming analysis, as elaborated by Benford and Snow, is a particularly useful way of revealing not only how the authorities construct their interpretation and understanding of "financial responsibility", but most importantly by which means this understanding is expected to be communicated for high school students to adopt. First, the analysis of the diagnostic an $\mathrm{d}$ prognostic fram ings asks qu estions about what the public authorities believe to be the problem and solu tion for the situation at hand. Together these framings ar ticulate the authoritie s' view on how to understand the idea of financial responsibility. Second, the an alysis of the $\mathrm{m}$ otivational framing reveals the guiding assumptions by which the authorities chose to introduce their view of financial responsibility to high school students. Such an analysis is not only restricted to an exam ination of the rhetorical arguments used in speech or written statements, but it also takes into account th e potential use of non-discursive resources a nd technical devices by which activities are arranged in the high school setting.

Apart from providing the paper with its theoretical underpinnings, the structure of the framing analysis has also brought about useful methodological advantages, which will be accounted for in the following section.

\section{Design of Study}

In lin e with the f raming m odel elaborat ed on earlier in Section 3, the data analysis aims at identifying illus trations of the activities corresponding to those that $\mathrm{m}$ ake up 
the three core fram ing tasks: diagnostic, prognostic and $m$ otivational fram ing, respectively. The empirical search for these illustrations was oriented by two main purposes:

a) To pinpoint the particular meaning of financial responsibility as envisioned and perceived by the public authorities themselves (diagnostic/prognostic framing), and then

b) To explore by which means this meaning is communicated to fit the high school students in their classroom settings (motivational framing).

The total co rpus of the data $\mathrm{m}$ aterial was then divided and classified in accordan ce with the three core fram ing tas $\mathrm{ks}$. In collecting and analysing the $\mathrm{m}$ aterial, discursive and/or calculative representations of how problem s and solutions were depicted and rela ted, as well as how $\mathrm{m}$ otives for financial responsibility were communicated, were sought. Of par ticular interest was to inves tigate if/how ac counting and kindred calculative pr actices were used as pedagogical means for motivating students to take further interest in the m anagement of their personal financial affairs.

The study rests on a ran ge of data collected by em ploying multiple information sources and various $\mathrm{m}$ ethodological techniques. Th e em pirical $\mathrm{m}$ aterial is partly based on texts published as reports, bulletins, articles , and press releases by both international organisations such as the Organisation fo $\mathrm{r}$ Econom ic Co-Operation and Developm ent (OECD) and the European Union (EU), and the Swedish political a nd public authorities involved su ch as the $\mathrm{M}$ inistry of Finance, the Financial $\mathrm{M}$ arkets Advisory Committee, th e Financial S upervisory Authority, the Enforc ement Authority, and the Consum er Agency. Apart from this archival data, the material also comprises 10 interviews and four occasions of in situ participation in high schools. The data collection was carried out during the period of February 20 08-March 2009 . In addition, durin $\mathrm{g}$ the sam e period, the $\mathrm{m}$ edia coverage of financial education issues on Swedish televisi on and in radio and $\mathrm{m}$ orning newspapers was observed.

The interviews were of a traditional semi-structured kind, involving a set of open-ended questions for the interviewees to el aborate on. In order to give the interviews a less formal character and become more conversational, most of them were performed without taking notes. Instead, the dialogues during seven of ten total occasions were recorded and then transcribed. The lengths of the interviews vari ed between one to two hours and took place in the inform ants' offices, apart from two that were carried out at cafés. The infor mants-10 civil servants and political advi sors at the aforem entioned Swedish authorities-were chosen 
due to their roles in the initiation and/or implementation of the financial education programme in general, and/or the high school tour in particular. During the interviews, they were asked to give their subjective views and opinions on different $\mathrm{m}$ atters related to the background, purposes and implementation of the programme and/or school tour.

The high school tour, conducted in September-November 2008, com prised 24 stops in cities all over Sweden. On four occas ions, passive participatio n was taken on-site , observing the activities in class and taking written notes. These occasions were critical to the analysis of this paper, as they offered an oppor tunity to personally witness what was actually said and done at the site where the core message of th e school tour was conveyed. Furthermore, most of these activities were pe rformed to illustra te the a rguments in a short film produced to form a point of departure for the student discussion in class. It was casted as a fictional lifestyle talk show covering financial and consumption issues to reflect upon when moving away from home. The short film, together with the teacher instruction specifically produced to encourage discussions in class, cons tituted an important source of information to the analysis. Moreover, a portfolio suggesting useful teaching $\mathrm{m}$ aterial such as text and exercise books, and brochures and $\mathrm{m}$ agazines produced by the public authorities involved, were also used as additional input for the analysis.

Asking questions about the connections between cause and remedy, and how they are elaborated and com municated, has served as a methodological manual for this paper. The empirical results of the study are presented and discussed accordingly. First, the problems and causes of financial illiteracy are addressed in the section of diagnostic framing (5.1). Second, in the subsequent section of prognostic fram ing (5.2), an elaboration of how financial education is suggested to rem edy the probl em in question is presented. Together, the diagnostic/prognostic articulations form the as semblage of a fram e, infor ming how to understand "financial responsibility". Third, the pa per explores the strategies that build the motivational framing (5.3), investigating how the frame is communicated in order to align the perception of the high school students. The thr ee sections end with a concluding discussion (6) where the empirical findings are further elaborated. 


\section{Framing Financial Responsibility - the Case}

\subsection{Diagnostic Framing: “What is the Problem?”}

If one is to understand wh at led to the fact that a number of Swedish public authorities eventually chose to go on a road show school tour, one $\mathrm{m}$ ust take into consideration how the initiators understand and articu late the prob lem in ques tion. Problem settings are mediated by the st ories people tell about troublesome situations, stories in which they describe what is $\mathrm{w}$ rong and $\mathrm{w}$ hat need s fixing (Schön, 1979). Pinpointing problem atic issues and c onditions about the citiz ens' financial capability is thus the first step in a fram e transformation process (Snow et al, 1986), aiming at redefining the way people look upon themselves as financially responsible. In th e following section, the paper elaborates on a couple of issues addressing the causes for introducing financial e ducation measures in order to improve Swedish citizens' financial capability.

As financial products and services real ise people's housin g, studies, pensions, security, daycare, leisure, and health more so now than ever before, financial decision-making has become an important element in people's everyday lives. The first, rather obvious reason for introducing financial education would be that people are not considered capable of taking care of their own financial affairs. Th is assumption has been confirm ed (cf. Finansmarknadsrådet, 2007a: 45), or at least in part. According to a su rvey investigating the financial capability of Swedis h citizens, "The $\mathrm{m}$ ain part of the Swedish households has a strong financial position and keeps a great d eal for personal savings" (2007a: 2). A project manager at the Financial Supervisory Authority (FSA) explained:

Well, if you look at the results of the survey (...) we are not that bad of taking care of our personal finances in Sweden. Actually, compared to many other countries, I would say that we are good. If you look here and now, there is no case of emergency. (...) So, it's not that the situation in Sweden today is critical or difficult in any way, it's more about what is about to happen.

What is implied is that people are standing before, or perhaps even in the midst of, a major shift of "demographic, economic and policy changes" (OECD, 2005: 10). Some of the interviewees refer to it as "dramatic", "something completely different to what we grew up to know", or "som ething terribly com plicated". However people try to de cipher it, the increase and complexity of financial products, the e xpanding amount of infor mation, the intensified electronic use for finan cial transactions, the escalating availabil ity of credit, and the changes 
in pension arrangem ents (OECD, 2005, 2006) ar e all factors claimed to transf orm the everyday financia 1 life of each and every one of us, ultim ately de manding more of an individual's financial capacity than ever before.

In fact, over the recent years a sub stantial part of financial decision-making has been displaced, transferred from $t$ he Swedish state and the $f$ inancial institution $s$ to the individual. Citizen s are increasingly being a sked to a ssume responsibility for complex long term savings tasks that were previously shar ed with the governm ent and e mployers such as investing for one's pension. Hence, financia $1 \mathrm{~m}$ atters that have a major im pact on a $\mathrm{n}$ individual's future, and that prev iously used to be affairs of the sta te, are currently becoming an individual concern. Accordi ng to financial experts, today there is no such th ing as a financial market free of risks on which consumers can expect to be protected from all kinds of non-successful transactions. Although public consumer protection is necessary, it is crucial to declare that consum ers $\mathrm{m}$ ust be able to ta ke personal responsibility (Finansinspektionen, 2007a: 45). A project manager at the Financial Supervisory Authority explained:

Sometimes they say that society has withdrawn from its responsibility to protect people. I'm not sure it's like that. It's more like allowing the individual to decide more for himself. I don't think society is withdrawing from its responsibility. On the contrary, the balance between the responsibility I take on and the responsibility society assume is better. (...) So at the end of the day, this is something positive.

Similar to Finlayson (2009), it is argue d that the transfer of risk and responsibility of the financial we lfare from the collec tive to the individual has resulted in a "reduction of distance between high fina nce and everyday life" (2009: 402). Personal financial investing is thus required to be made into a norm al and regular activity, particularly in countries where "th e word finance was an athema a m ere decade ago" (Preda, 200 1: 229). Today, a true and modern citizen is expected to engage in investment-decision problems, and take in terest in $\mathrm{f}$ inancial issues th at only a few years ago $\mathrm{w}$ ere too obs cure for the average person such as the qu estion of how to save for one's retire ment or to decide on one's risk investment profile. So what was previously seen as a concern for the state, and perhaps a bit of an eccen tric side activity performed by a $\mathrm{m}$ inority of the population, is now bein $\mathrm{g}$ turned into something that is expected of everyone everyday.

Due to this shift in responsibility, th e dem ands of what it $m$ eans to behave financially responsibly have sharpened to re quire a certain kind of knowledge. However, as several of the interviewees argue: "There are very few who possess this knowledge of how to 
make wise, well-informed decisions". So in spite of the positive results concerning the state of Swedish financial capability, surveys also confirm substantial gaps. The results reveal that the financial awareness of conditions for future pensions is poor, and moreover, that people rarely compare or look for other financial alternatives apart from those being proposed to them by financial advisers (Finansinspektionen, 2007a: $\quad 2$ ). This means that people do not $\mathrm{m}$ ake financial provisions for the future or choose the products that best $m$ eet their needs. Or even worse, they do not choose at all. In effect, people are not considered to be financially engaged enough, and are not taking advantage of the increased freedom of choice that has been offered to them. But why? A senior manager at the Financial Supervisory Authority explained:

Whether you're a pro or an ordinary mortal, you can't keep track of this any longer. It's almost impossible. All those choices, all those funds, loans, instruments, pensions (...) You will eventually end up with a situation where the capacity of the individual does not make do anymore.

People's financial capability has thus not been able to $\mathrm{k}$ eep up with societal development. The Financial Supervisory Authority warns that if $\mathrm{m}$ easures are not taken to equip the public with the required abilities, people lacking the necessary financial disposition will face severe consequences. As financially illiterate, it is argued that they are more likely to be forced to cope with high levels of over-indebtedness, in adequate pension incom e, and situations that ultim ately might end up in pe rsonal ruin, bankruptcy a nd financial isolation (OECD, 2006; Finansmarknadsrådet, 2007a, 2007b).

Apart from the individual himself running the risk of ending up impoverished and indebted for life, there are others rendered as victims due to the poor financial capability of ordinary people. This issue concerns a $\mathrm{m}$ atter that is $\mathrm{m}$ ore often than not pointed out by actors representing the governm ent or the financ ial industry. The point is well elaborated on in a repo rt published by the Swedish Financial Markets Advisory Comm ittee (Finansmarknadsrådet, 2007a). The comm ittee is appoin ted by the Swedish govern ment for "issuing ad vice aim ed at prom oting the d evelopment of the financial secto $\mathrm{r}$ in $\mathrm{S}$ weden" (Finansmarknadsrådet, 2007b: 1). The report stat es this is affected by the confidence people have in the financial industry. And on this point the report is clear: "In this area [confidence] improvements are definitely needed" (Finansmarknadsrådet, 2007b: 2). According to surveys measuring attitudes towards the financ ial sector (see Prospera Research 2007

\footnotetext{
${ }^{4}$ Surveys were conducted in 2006 by Prospera Research AB by order of Stockholm Financial Centre and Financial Markets Advisory Committee.
} 
Finansinspektionen $2007 \mathrm{a}^{5}$ ), Swedish citizens rank the sincerity of the financial industry low due to ethical scandals, arbitrary bonus system s, unreliable financial advisors, and com plex financial products (see also Finansinspektio nen, 2007a; Finansm arknadsrådet, 2007a: 34). The committee por trays the genera 1 public's lack of faith and negative at titude as potential threats to th e m easures that $\mathrm{m}$ ust be taken to strengthen the financia 1 sector, depicted as representing "the life-blood of the economy" (Finansmarknadsrådet, 2007b: 1).

Although the committee calls for a certain de gree of regulation and internal selfexamination to restore its reputation, it argues that "if the industry finds the negative attitudes unjustified, then there is need for public know ledge building" (Finansmarknadsrådet, 2007a). The committee suggests that the reason for people' s lack of support might not exclusively be a question of a deprived intern al culture, but a result of their poor understa nding of the financial s ector's operating conditions. A politi cal adv isor at the Minis try of Finance explained:

We feel that the open competition, in that there are a number of different actors offering products in the financial market, it works, but the consumers proved in several respects (...) that there are in fact weaknesses regarding their consumer behaviour. (...) If the customers would have possessed the knowledge, how many would have accepted these bad loans? So, much could be attributed, of the bad stuff going on in the financial market, to the customers' poor knowledge.

This point is confirm ed by surveys invest igating consum ers' financial behaviour (Prospera_Research, 2007), revealing that Sw edish citizens are regarded as having insufficient financial knowledge. A senior $m$ anager at the Financial Supervisory Authority concludes the point made:

I think that the problem that one perceives, as a threat at least, is that the customers start to become a restriction to a well functioning market. (...) It is not so much a question of saving people from ruin, but to make the market function better.

The committee argues that people's inadequate knowledge affects "their possibilities to make rational financial decisions" (Finansm arknadsrådet, 2007a: 45), which in turn has a negative impact on the condition s for the financial $\mathrm{m}$ arket to function successfully. Swedes, referred to as $\mathrm{f}$ inancially illiter ate citiz ens, are thus $\mathrm{p}$ ortrayed as a potentia 1 threat no $t$ only to

\footnotetext{
${ }^{5}$ Survey was conducted in 2007 by the Financial Supervisory Authority
} 
themselves, running the risk of ending up fina ncially isolated, but also as an obstacle preventing the market from performing effectively.

By dem onstrating how people's incom petence for making everyday financial choices affects their well-being and the nation negatively, people are diagnosed as financially deficient subjects (Knights and McLean, 1998), unable to live up to their financial civic duties. Financial illiteracy is thus framed as a problem placed within the individual and to be understood as something that not only the indi vidual cannot afford but also Swedish society as a whole. This problem atisation serves as a starting po int in the au thorities' process of converting people into experiencing them selves and their finances in funda mentally new ways.

\subsection{Prognostic Framing: “What is the Remedy?”}

In the last s ection, it w as concluded that the financial capability of the Swedish population does not $\mathrm{m}$ eet the required expectations of a financially resp onsible citizen. It is argued that technological, econom ic and social developm ents have in fundamental ways changed the conditions of conte mporary living, demanding more of the citizen's a bility to concern them selves with their own finances. But in sp ite of extensive public information efforts, people still do not act in $\mathrm{f}$ avour of th eir own financial needs. Or as the Financial Supervisory Authority put it:

Not even vast amounts of information is enough; one also has to take into consideration how people learn about the information, how they process it, and the capacity people possess to do so. (...) And then you realise that financial education becomes a key matter.

What is implied is that the concept of fi nancial illiteracy is to be understood quite literally. The reason $\mathrm{w}$ hy people suffer from fi nancial illiteracy is not a result of poor information supply but of people's inability to understand the information at hand. In view of the fact that all too $\mathrm{m}$ any European citizens lack this basic knowledge, Internal Market and Services Commissioner Charlie McCreevy explains that financial education is "a key elem ent in empowering our citizens to take more appropriate financial decisions" (EU Press release, 2007b). But what specifically should be taught? And what does it in fact $m$ ean to build financial capacity? In this section, the paper outlines an account of the components claimed to constitute financial capability and the ways it is declared to remedy the problems in question. 
Knowing how to $\mathrm{m}$ ake sense of financial information, and even $\mathrm{m}$ ore how to act upon it, is rarely som ething most individuals know by heart. This is a point well highlighted by the Swedish Financial Markets Advisory C ommittee, who stress that in cases where the state delegates responsibility to the general public, as it did regarding Swedish pension decisions, it is also the state 's concern to "ensure that people are put in a reasonable position to take such responsibility" (Finansm arknadsrådet, 2007b: 2). Confronted with the fact that the mere introduction of the new pension syst em was not enough to $\mathrm{m}$ ake people sufficiently financially self-propelled, the state does ackno wledge a certain degree of liability. A political advisor at the Min istry of Finance adm its that "it has got a bit out of hand here", regretting that additional supportive $m$ easures were no $t$ taken in advance be fore introducing an individually self-steering sy stem. However, the Swedish governm ent now unde rstands its duty is to "straighten things out":

We believe people should decide for themselves. That's our political point of departure, and that permeates most of what we're doing. (...) However, we do realise that in order to take on responsibility, the state needs to be supportive. Because one cannot just assume that people know how to undertake a responsibility. So, the state's role is to support people to make good decisions, well-informed decisions. That's why this [financial education] programme has developed.

In spite of the government's general stance not to interfere in individual affairs, it now announces it will actively support and "em power people to take control of their own everyday lives". A political advisor at the Ministry of Finance clarified:

We say, 'Ok sorry, this is not our responsibility, it's yours, but we will make sure you'll get what is required for taking on that responsibility'.

Hence, in this new world of order, the citizen s m ust be able to assum e a greater personal responsibility for their own financial affairs, and the state's responsibility is to make sure they do. But what specifically are those requirements? What is that knowledge which is assumed to put people in a reasonable position to take on financial responsibility?

In a bulletin (European Comm ission, 2007, see also OECD, 2005), the European Commission declared that financial education might im ply different meanings as the level of financial illiteracy varies considerably between different individuals. At one point it states that "financial education is the $\mathrm{p}$ rocess by whic $\mathrm{h}$ individuals im prove their understanding of financial products and concepts". This $\mathrm{m}$ ight correspond to an education oriented towards giving participants an introduction to som e core concep ts of the financial vocabulary, 
presenting an overview of diffe rent $\mathrm{f}$ inancial altern atives or teaching them som e basic calculations. However, this is not primarily what the Swedish Financial Supervisory Authority has in mind, at least not initially. One of its employees elaborated:

[Financial education] is not about learning the name of different kinds of accounts or funds. It's not a matter of knowing that much of financial details. I don't even think you need to know different kinds of instruments. (...) It's about reaching some kind of awareness and insight.

Highly influenced by the British financial edu cation programme and the experiences created by the $\mathrm{OE} \mathrm{CD}$ and the EU, it emphasises that the $\mathrm{f}$ irst goal of the $\mathrm{f}$ inancial e ducation programme is to increase people's awareness of their own need for financial information:

If consumers are not aware they need financial information, they will not seek it out. Thus policymakers need to think about the best ways to reach these consumers and convince them that they need financial education. (OECD, 2005: 45)

The argum ent is that as long as pe ople do not acknowledge them selves as financially illiterate, they woul $\mathrm{d}$ hardly bother to seek financia 1 information. This m eans that in order to be open and responsive to financial de tails, people must first be made aware of the fact that a) they are financially illiterate, b) illiteracy is bad, and c) their illite racy needs to be remedied. Put shortly, people need to be $\mathrm{m}$ ade aware of their own financial deficiencies. However, the authorities claim such awar eness cannot be achieved by providing $\mathrm{m}$ ore financial in formation because as long as pe ople do not appreciate them selves as activ e decision-making consumers in the $\mathrm{m}$ arketplace, they will $\mathrm{n}$ ot be able to understan $\mathrm{d}$, or even less respond, to the financial in formation offered to them . Given this lim itation, it is instead argued that people first need to be equipped with "a certain kind of ethos or orientation towards finance and towards the self' (Finlayson, 2009: 411). Once charged with this attitude, people will be open to learn from the financia $1 \mathrm{inf}$ ormation that pro vides them with the knowledge and guidelines on how to go about as investors and self-regulating citizens.

Hence, the financial education, as referre $\mathrm{d}$ to by the public au thorities, is of a reconstitutive kind "cen tered less on what lear ners know or can do than on the remaking of the individual" (Williams, 2007: 247). It is abou $t$ an educatio $n$ that first and forem ost makes people perceive them selves differe ntly, in other ways than they did before. So if financial information will not make that happen, what will then? According to a project manager at the Consumer Agency, the first stage of financial e ducation is to get peop le to understand life as an act of constantly making choices: 
It's about making them understand that you make choices, that you always make choices, but that the choices have to be actively made.

This view is shared by the Ministry of Finance and decl ared as central. In order for a financially responsible person to $\mathrm{m}$ ake sound decisions, he needs to be aware of his options and capable of reflecting upon his choi ces. This choice-m aking capacity is thus portrayed as a prerequisite for engaging in responsible financ ial decision-making. A political advisor at the $\mathrm{m}$ inistry defines th is capacity $\mathrm{b}$ y dividing it into two levels. The first level concerns that which is already m entioned: to accept life as choice, as a way of living. This is essential, because even in spit e of the risk of ch oice overload - in other words that too $m$ any opportunities of free choice poten tially would make people less motivated, or even incapable, to commit to the a ct of choice-it is simply concluded that there is no such th ing in life as a non-choice. Or as put by the politi cal advisor: "Well, life's hard. Y ou just have to realise that life is about making choices". Financial illiteracy is thus suggest ed to be cured by an attitude change, emphasising that in or der to transf orm into a $\mathrm{f}$ inancially responsible consum er, one needs to not only make choices whenever one wishes but whenever it is called for.

The second level of active choice-making involves an understanding that choices always entail consequences. The political advisor clarified:

People have to be aware of the long-term consequences of the choices they make today. If you spend all your money today, well then you end up in a one-room flat with a kitchenette, eating cat food, to be a bit cruel. But indeed, there's no such thing as a free lunch. You can't have your cake and eat it. It's a bore, but life is in a way quite boring.

He points to an evaluative capacity that is ba sed on the appreciation that what you put in today will eventually affect your life later on. It is suggested that "the connection between your own achievem ent and what you actually get out in the end has to be $\mathrm{m}$ ade distinct". Therefore, the general idea is to teach people how to think in te rms of options an $\mathrm{d}$ how to evaluate their choices made. A project manager at the Consumer Agency summarised:

First I have to realise that I have different options, and then I have to find out what the different options mean. It takes a certain capability to be able to do so. Being able to see that.

Hence, the essence of financial educa tion is not understood as an issue of introducing financial concepts or calculative tools. Instead, it is about laying a foundation for a choice-m aking capacity that is perceiv ed as a pre-stage for making sense of financial information in a subsequent phase. As rational decision-m aking is claim ed a s a core 
competency in financial 1 iteracy (Rem und, 2010), $\mathrm{m}$ aking a nd reflecting on choices is announced to be at the very heart of what initi ally needs to be taught. This corresponds to what Miller and Rose call econom ic citizenship, where people ar e expected to be "active and individualistic rather than passi ve and dependent (...) m anifested through the free exercise of personal choice am ongst a variety of options " (1990: 24, see also Rose, 1999). By linking citizenry to choice-m aking duties, the citizen is redefined as a consum er. This refram ing changes the notion of civic res ponsibility, tran slates it into financial term s and turns the freedom of choice into an obligation.

Apart from ensuring the financial well-being of individuals, financial education is also cla imed to im prove the f unctioning of the financial market. Or as W illiams puts it, "Beyond managing the business of her own lif e, the work of the resp onsibilized consumer extends to regulating the behaviour or firms and the performance of the markets" (2007: 227). However, in the previous section it was concluded that the public's confidence in the financial sector is poor. Representatives of the financia 1 industry and the government portray this lack of support not just as a result of the inappropriate ways financial businesses are run, but rather due to a public $m$ isconception of the way the fina ncial sector functions. Therefore, the sector is said to be nefit from public f inancial education, as it $\mathrm{m}$ ost likely would im prove people's understanding of and c onfidence in the financial industry. A political advisor at the Ministry of Finance explained:

The Swedish people cheer when Ericsson and Volvo do well. But if the banks make big money, then danger threatens, and people call for political action. (...) This is about how to confront a social problem. Is it by pointing the finger [at the banks], saying that you have to lower your prices? Or is it to say that we have to support the market by making customers get better at making demands.

The claim is that more financially confident choice making customers will like ly challenge financial service providers to develop products that truly res pond to their needs, which is considered to have positive effects for bot $\mathrm{h}$ individual and national econom ic grow th. The line of argum ent seem $\mathrm{s}$ to be based on the maxim that "the $\mathrm{m}$ ore competent and active participants in the financial market, the more functional it gets" (Belfrage, 2007: 78).

To sum up, the individual's financial illi teracy is framed as a problem not only to the illite rate him self, but also to the econo mic health of the natio $\mathrm{n}$. The citiz en is now expected to play the role of a respo nsible self-regulating subject "w ho does not look to the 
state for more help th an it is willing to provide" (W illiams, 2007: 233), and whose responsibility is to be an activ e, choice-m aking participan $\mathrm{t}$ in the $\mathrm{m}$ arketplace. However, these are ex pectations that Swedes are not cons idered to su fficiently meet. Accord ing to the authorities, this dem ands a change in the indi vidual's relationship with finance and in their attitude towards m oney from, what Finlayson describes, "an old-fashioned focus on wages, cash and short-term expenditure towards a new-economy focus on wealth and assets, savings and investments for the long te rm" (2009: 411). W ith this being the case, Swedish financial education aspires to a subjec $\mathrm{t}$-formation, infusing people with a choice-m aking rationality that spurs them on to look at them selves as investors, consum ers and autonom ous decisionmakers (Greenfield and Williams, 2007).

In 2008, the Swedish financial education programme was launched. Depicted as a joint venture, the Minister presented the first steps in Swed en's official strategy to fight its national financial illiteracy. Coordinated an d supervised by the Financial Supervisory Authority, the programm e's activities were in itially o riented towards two $\mathrm{m}$ ain targets : pensions and young students. In section $5 \quad$.3 Motivational framing, the specific co urse of action of the latter is elaborated as an illus tration of how the authorities' idea of financial responsibility is translated into its intended audience.

\subsection{Motivational Framing: "Why Should They Bother?”}

Up to this point, it has been $m$ ade clear that $\mathrm{S}$ wedish financial illiteracy causes potential problem s both to the individual and soci ety, and is assum ed to be a result of the Swedes' in ability to ke ep up with the demands of the changing conditions of contemporary life. Their illiteracy is suggested to be remedied by financial education, equipping people with an appropr iate choice-making attitude that is a pre-condition for $\mathrm{m}$ aking financial decisions. The result of these $\mathrm{d}$ iagnostic/prognostic ac tivities form s a choice-m aking consum er frame, informing how to understand and conceptualise a "financially responsib le person". In this section, the paper turns to explore the st rategies that build the authorities' motivational framing, investigating by which $\mathrm{m}$ eans the choi ce-making consum er fra me is introduced to high school students.

It is a general recomm endation that financial educational activities should target specific groups at the "receiving end" such as schools, workplaces and welfare centres, and be personally tailored an d as easily accessibl e as possible (Fin ansinspektionen, 2007b, 
Finansmarknadsrådet, 2007a; OECD, 2005, 2006). In accordance with m ost other countries, Sweden chooses to invest its in itial activities in high school students. The reasons for this are threefold. First, as financial capability is a ssumed to support the $\mathrm{i}$ ndividual throughout life, "financial education should start at school, for people to be educated as early as possible" (OECD, 2006: 3). Second, and in c ontrast with other areas of society, the nature of school offers an ideal ins titution for educational activ ities, because it is where one specifically goes to learn. Third, as young people are considered to be particul arly vulnerable to the growing pressures of consum ption, suffer from ever incr easing credit card debts, and lack experience with regard to running a household, they pose an exceptionally worrying problem (Kronofogden and Konsum entverket, 2008). This involves $\mathrm{m}$ eeting $\mathrm{m}$ ajor financial challenges. Thus, targeting high school students is presented as something well-founded and quite evident.

Consequently, and as a joint ventur e between three pub lic authoritie $\mathrm{s}^{6}$, a high school tour called 'Check up your cash' $\quad{ }^{7}$ was conducted during the autum n of 2008. At schools, the authority repres entatives introduced a teac hing package and an on-site demonstration of how the $\mathrm{m}$ aterial $\mathrm{m}$ ay be us ed in class. The intention was to convince teachers to $\mathrm{m}$ ake personal financial $\mathrm{m}$ anagement part of th eir own subjects. The authorities involved op enly ackno wledged that the tour $d$ oes not provide the kn owledge necessary for turning the students into full-fledged financially capable subject s. However, this was not its goal. A project manager from the Enforcement Authority clarified:

First of all, it's about making people take an interest in these issues. Then after, it would be great if the school would provide the [financial] information, and give them the opportunity to work with it. But that is something we can't do on this tour. This is an introduction for learning more.

According to the interviewees, the tour was first and fo remost about cultivating an interest or an attitude to wards one's own fina nces in the hope of making young people eventually s ee that in o rder to $\mathrm{m}$ ake wise financial decisions, one must seek appropriate information and learn how to calculate. One of the tour organisers from the Consumer Agency declared that such an approach requires careful pedagogical considerations:

\footnotetext{
${ }^{6}$ The Financial Supervisory Authority (FSA), the Enforcement Authority (EA) and the Consumer Agency (CA).

${ }^{7}$ Author's translation of "Koll på cashen" (Swedish).
} 
There is a great interest for these [financial] issues, if you introduce them right. If you challenge them [the students] properly and not just draw up a budget template. (...) Because it all starts with the thinking.

Hence, the school tour organisers argued that before initia ting students into understanding financial details and concepts, or m aking use of various budget tools, their attitude towards $m$ oney must be worked on, ul timately showing them how their choices of spending money affects the lives they live today. Otherwise, the risk of students lo sing their interest is imminent, or as one of the project managers put it:

It would have been suicide, standing there making up a budget with them. Because that's no fun for the receiver (...), it wouldn't have been appealing.

So then, if financial education is not in itially about introducing students to everyday calculations, what is it then? W hat does it m ean to cultivate an choi ce-making attitude? And how is this to be done in the classroom setting?

According to the OECD, students are in cluded among those who often "conside $r$ financial matters to be a source of stress, anxiety and confus ion, or are uninterested in th e future" (OECD, 2005: 55). Therefore, financia leducational activitie s are suggested to emphasise simple, present-day bene fits, and to be explicit and di rect. As an attem pt to $m$ eet these demands, a short film was produced and pr esented to the stud ents in class, forming a point of departure for student discussion. In a fictional talk show setting, the viewers $\mathrm{m}$ ake acquaintances with a couple of ordinary young peopl e who invite them into their lif e to take part in their everyday activities of spending and saving. One of the sc hool tour organisers clarified the theme of the film:

This talk show concept got us going. Because they [the producers] had the right approach to it. They were not so deadly serious. They did not take economy so terribly hard, and they could present it in a way that made it more accessible.

The final form at was preceded by form ing focus groups who previewed the film, followed by in-dep th in terviews with both te achers and s tudents to dis cuss the manuscript. The purpose was to find a well-adjusted $\mathrm{m}$ ix between the difficult and the $\mathrm{m}$ ore easy-going, and to pinpoint credible characters and realistic situations that students could relate to. It was also important to identify the appropriate tone of language and to use a vocabulary that suited 
high school students. According to the tour organisers, ente ring the students' world by taking "a proactive perspective on what it means to grow up" was critical in order to be listened to:

We wanted to get it as realistic as possible. We really wanted to have it down to earth, because then the students would be able to relate.

The film covered different topi cs related to iss ues such as moving away from home, the credit lo an dilemm a, everyday consum ption habits, and how to think about savings.

(Finansinspektionen, Konsumentverket, 2008). It is, however, em phasised by the organisers that the scope of each topic was kept short and simple:

We're just scratching on the surface of these topics. Just to touch it a bit. Because how interesting would the film be if you got deep with [financial] details? Then for sure, the students would fall asleep.

In addition, to avoid the risk of being viewed as "boring, dull and out-of-date", the film was supplem ented by a teacher's guide especially designed to suit the talk show topics with suggestions on how to "construct s cenarios to $\mathrm{m}$ ake the di scussions [in class] come more alive" (Finansinspektionen, Konsum entverket, 2008). Som e of these scenarios were called value exercises. Here, the students encountered va rious ethical dilemm as related to their own lives in which they are asked to a) make their own decisions and then, b) discuss how they reached their decisions. The ethical scenarios were chosen to correspond to the talk show topics listed abov e and inclu ded themes such as: Why do you buy things you cannot afford? How are you (not) affected by commercials? How does a debt you cannot pay affect your relation to your best friend? Is playing poker a way of investment?

In one such scenario, the students were hypothetically given 1,000 euros as a gift from their grandm other. They are then gi ven the cho ice of spe nding or saving it. The instruction was as follows:

Grandmother was working hard all her life for you to have this money. So think carefully before spending it! (...) You simply do not know what to do. Should you save it or buy that great computer you've wanted for over a year now? What would you do with the money and is your decision affected by how you got it (as a gift or by work)?

The purpose with this $\mathrm{k}$ ind of exercise is to as $\mathrm{k}$ the stud ents to articu late how they reach a decision, ultimately revealing to themselves what seems to be of relevance when it com es to their own financial decisions. Li ke this, the s tudents a re given the opportunity to exam ine their own mode of reasoning, or as the organi sers put it: "Ou r goal is to get young people to 
reflect upon their choices and find out if th ere are any alternatives " (Finansinspektionen, Konsumentverket, 2008). The organisers em phasised, however, that they were not there to lecture, teaching the students how to make right choices and not the wrong ones, saying, "Do this and you do right". Instead, "we wanted to communicate, to dem onstrate that you're [the student] in control, that you make the calls". One of the organisers elaborated on the purpose:

We didn't want to put any blinders on; the students were free to have any opinion they wanted about financial matters. If they find blackmarket labour ok, so be it. Nothing wrong with that. But they should know the consequences too.

On other oc casions, the exercises in class were designed according to a multiple choice principle. In one such instance, the students were put into the hypothetical situation of going to a music festival they cannot afford. They are then asked to pick one option that best corresponds to their own habitual pattern of decision making:

a) stay at home

b) borrow money from parents, friends or take a small credit loan

c) work at the music festival for free

The students were then instructed to reveal their decisions individually by standing in one of the room 's corners, each of which repres ented one of the optional alternatives. A project manager at the Consumer Agency explained:

The value exercises are about making choices physically, to physically move about, to be able to account for one's choices, and to argue why. Some stayed, but we forced them to choose. They were not allowed to stay. It was not in itself an option.

The subsequent discussi on in clas s aim ed at demonstrating that diffe rent op tions enta il different consequences, and that the choices you m ake everyday also affect ot her parts and relations of your life-here, now and in the future. According to one of the organising participants, the value exercises helped students "see that they make choices", that they in fact always $\mathrm{m}$ ake choices independent of whic $\mathrm{h}$ decision they $\mathrm{m}$ ake. Like this, it was demonstrated that there is no such thing as a no n-choice in life, and by physically forcing the students to take a stand, the organisers in fact "wanted them to feel that".

According to the organisers', turning students into financially active citizens should not be done through calculativ e tools or financial vocabularie $s$, as contradictory as it might seem. At least not initially. Instead, in order to introdu ce them to the behaviour of a 
responsible consumer, the students first need to acquire a certain awareness of how they relate to themselves and their current financial way of life. By confronting the students with morally complex everyday scenarios, they are forced to reflect on how they reach financial decisions, along with the pros and cons that those decisions entail. The lesson to be learned, according to the organisers, is that before any number-ori ented financial decision-making can be put into action, a specific understanding of financial decision-making as such must framed, portraying the individual's financial activities as an active choice-making venture.

\section{Discussion}

Goffman ar gues that "whatever else, our activity $m$ ust be addressed to the other's capacity to read our words and actions for evidence of our feelings, thoughts, and intent" (1983: 53). Hence, framing, in the sense of meaning construction involves a thoughtful concern of how the receivers of a message believe things to be true, real or re asonable. This point is illustrated in the way the school tour or ganisers made their initial preparations. When communicating the consum er frame to the high school students, the organisers attem pted to adjust the way in which their $\mathrm{m}$ essage of fina ncial responsibility was presented. By tailoring the film and the value exercises in class in such a way that they clearly addres sed an $\mathrm{d}$ embraced the students' everyday experiences, the organisers hoped to get the students' attention, make them listen, and eventually invest in the message conveyed.

Nevertheless, given the large am ount of research ascribing to accounting a key role in responsibilisation processes, the relative void of calculative exercises $\mathrm{m}$ ight come out as a bit surprising. Therefore, it may be appropriate to turn to the Choudhurian question: Why do we find no accounting here (1988: 552)? Choudhury suggests that the absence of something as well as its presence contains information: in other words, what people do not do are data, which also needs to be taken into account. Not using calculative practices as a means of responsibilisation is not necessarily an act of ignorance or management failure. By contrast, Choudhury proposes that there $\mathrm{m}$ ight very well be instances where not using accounting is a result of a conscious de cision or where accounting voids are deliberately built in as part of a strategy. Hence, an inq uiry in to th e account ing absence m ight, as Catasús (200 8: 1005) recommends, bring forth the problems or limitations with its presence.

The characteristics of an environment wherein accounting was expected to occur but does no $\mathrm{t}$ are found in the con ditions that $\mathrm{c}$ onstitute the specific situation in question 
(Choudhury, 1988). In our case, this involves investig ating the high school circum stances under which accounting is chosen not to be used as a technology of responsibilisation. As opposed to adults in professional and organi sational settings, high school students are assumed not yet to be in charge of household finances or work unit accounts. They are as such believed to be ra ther unfamiliar with using calc ulative devices in their day-to-day activities. Due to this practical inexperience, students are not exp ected to actu ally und erstand the function of a budget for instance. $\mathrm{C}$ onsequently, introducing accounting tools and financial vocabularies to ensure high sc hool students adopt a respons ible attitude tow ards their financial activities are presumed to alienate the students, making them unable to relate to what is presen ted. Such an approach is theref ore argued to be inappropriate or even counterproductive to the responsibilisation process.

Hence, the public authorities argue that in order to $\mathrm{m}$ ake young people responsive to eventually engage in financial calculations, the students initially need to be charged with an active choice-m aking attitude towards the lives th ey lead today. Calculative practices are here claim ed to be mobilised through, and required as their preco ndition, "a discourse that provides patterned ways of unde rstanding and dealing with possible choices and decisions" (Clegg et al., 2007: 113). Budgeti ng and kindred accounting practices are thus not inherently im portant to the resp onsibilisation process. They only becom e so when the contextual circum stances allows th em to be mobilised (Kirk and Mouritsen, 1996 ) and, as Ahrens (1996) points out, before it can be mobilised, accounting must be acknowledged as a useful language and a relevant analytical $\mathrm{t}$ ool for $\mathrm{m}$ aking decisions. $\mathrm{T}$ he high school tour represents the initia $1 \mathrm{~s}$ tep of turn ing stude nts into $f$ inancially $r$ esponsible citizens by introducing a cho ice-making discourse cons idered to $\mathrm{p}$ recede and precond ition such an acknowledgement of calculative practices.

\section{Conclusions and Contributions}

However well established within peopl e's work settings, this paper is concerned with exam ining the relevance of accounting as a $\mathrm{m}$ eans to individualise responsibility in people's own pr ivate finances. By addressing th is issue, the paper seeks to contribute to the accou nting literature in two ways. The fi rst concerns the empirical level of investigation. Studying the financial responsibilisation of people at their personal level of life serves as a response to what Hopwood (1994), Miller (2007) and Jeacle (2009, 2010) am ong others call for: taking accounting research beyond the orga nisational borders of investigation 
and putting it in an everyday social context. As most prior accounting literature has been preoccupied with studying the ac tivities and phenom ena taking place within organisations, this pap er c ontrastingly targe ts th e sphere of people's personal financial $\mathrm{m}$ anagement - $\mathrm{a}$ field of investigation that for long has been disregarded and poorly examined (Llewellyn and Walker, 2000).

Second, the empirical findings add insights into how the utility of accounting is presumed to be lim ited in the sense that it is preconditioned by the abil ities of its potential users. As su ch, they pro blematise the direct tran sformative capacity of accounting and the role it has been given as a te chnology of responsibilisation. Miller and O' Leary (1987) state that accounting owes the potential to produce fi nancially responsible individuals. This paper does not oppose to such a claim but demonstrates that it is believ ed to serve as su ch only in so far as pe ople see the relevance of accountin $\mathrm{g}$ as supportive for $\mathrm{m}$ aking decisions. If not, accounting needs to be activated, or as Munro puts it "brou ght to life" (Munro, 1993: 256). This is to be done by taking a detour (Catasús, 20 10), or perhaps a step back. In this paper, it is argued that before accounting practices can be introduced to people, they must be endowed with a choice- $\mathrm{m}$ aking $\mathrm{m}$ indset. A choice- $\mathrm{m}$ aking discourse is thus claim ed to serve as a precondition for people to even tually becom e appreciative of accounting as a means for responsible decision-m aking. If such discourse is not initially in pla ce, it needs to be initiated.

An issue for future res earch would be to furth er inves tigate whether $\mathrm{k}$ indred responsibilisation $\mathrm{p}$ rocesses chang e in rela tion to oth er everyday $\mathrm{m}$ ilieus and $\mathrm{m}$ undane practices. If accounting, as Hopwood suggest $\mathrm{s}$, "becom es $\mathrm{m}$ ore influential in everyday affairs" (1994: 301), such research would advance and add im portant nuances to our understanding of the specific con ditions acco unting is mobilis ed (or not) as a mode of everyday intervention. 


\section{References}

Ahrens T. Financial and Operational M odes of Acc ountability: differing account of British a nd Ge rman managers. In: Munro R, Mou ritsen J, ed itors. Accountability: Power, Ethos \& the Technologies of Managing. London: International Thomas Brunson Press; 1996. p. 149-63.

Belfrage C. Den v illige, den tv eksamme, den hopplöse. En sven sk massin vesteringskultur. In: Lun dberg U, editor. Mellan folkbildning och fondrådgivning Nya perspektiv på pensionssystemet. Sto ckholm: In stitutet för framtidsstudier; 2007.

Belfrage C. Towards 'universal financialisation' in Sweden? Contemporary Politics. 2008;14:277-96.

Benford R D, Snow DA. Fr aming Pr ocesses and S ocial M ovements: An overview and Assessment. A nnual Review of Sociology. 2000;26:611.

Callon M. An Essay on Framing and Overflowing: economic externalities revisited by sociology. In: Callon M, editor. The Laws of the Market. Oxford: Blackwell Publishers/The Sociological Review; 1998.

Carnegie GD, W alker SP. Household accounting in Australia: a microhistorical study. Ac counting, Organizations and Society. 2007;20:210-36.

Carrington T. Framin g Au dit Failu re: Fo ur stud ies on audit qu ality discomforts [Dissertation ]. Sto ckholm: Stockholm University; 2007.

Catasús B. In search of accounting absence. Critical Perspectives on Accounting. 2008;19:1004-19.

Catasús B. Indicators as Tech nology: Deb ates on the link between indicators and action (unpublished paper). Presented at the Conference of European Accounting Association, in Istanbul, May 2010.

Choudhury N. Th e Seek ing of Accounting Where I t I s Not: Tow ards a th eory of non-accounting in organizational settings. Accounting, Organizations and Society. 1988;13:549-57.

Christensen M, Sk aerbaek P. Fram ing and Ov erflowing of Public Secto r Acco untability Innovations: A comparative study of reporting practices. Accounting, Auditing and Accountability Journal. 2007;20:101-32.

Clegg S, Kornberger M, Rhodes C. Business Ethics as Practice. British Journal of Management. 2007;18:107-22.

Czarniawska-Joerges B . M erchants o f M eaning. I n: Tu rner, edi tor. O rganizational Symbolism. Berl in: de Gruyter; 1990.

Entman RM. Framing U.S. Coverage of International News: Contrasts in Narratives of the KAL and Iran Air Incidents. Journal of Communication. 1991;41:6-27.

Erturk I, Fro ud J, Joh al S, Leaver A, Williams K. Th e democratization of fi nance? Promises, ou tcomes an d conditions. Review of International Political Economy. 2007;14:553 - 75.

EU_Pressrelease. Fi nancial services: $\mathrm{C}$ ommission e ncourages better $\mathrm{f}$ inancial e ducation for EU citizens, IP/07/1954. Brussels: Europa Pressreleases Rapid, 18 December 2007b.

European Commission. Bulletin of the European Union 12-2007. 2007.

Financial Services Authorities. Building Financial Capability in the UK. London: FSA; 2003.

Finansinspektionen. Hushållens ekonomiska förmåga: en studie i hur hushållen klarar sin ekonomi, 2007-06-27. Stockholm 2007a.

Finansinspektionen. Aktionsplan för småspararna - en handlingsplan i tio punkter. Rapport 2007:20. Stockholm; $2007 b$.

Finansinspektionen, Konsumentverket, Kronofogden. Koll på cashen: Tre myndigheter. En skolturné. 2008. 
Finansmarknadsrådet. Finansiell folkbildning - ett exempel från Storbritannien. Fi2006:06. Stockholm 2006.

Finansmarknadsrådet. Samlad satsning på finansiell sektor - en gemensam grund. Stockholm 2007a.

Finansmarknadsrådet. Samlad satsning på finansiell sektor - en gemensam grund. Executive summary - Report 1. Stockholm 2007b.

Finlayson A. Financialisation, Finan cial Literacy a nd Asset-Based Welfare. The British Journ al of Politics \& International Relations. 2009;11:400-21.

Fisher F. Refra ming Public Policy. Discu rsive Po litics Delibertative Practices. New York: Ox ford University Press; 2003.

Froud J, Leaver A, W illiams K, Zhang W. Th e quiet panic about financial ill iteracy. In: Assassi L, Wigan D, Nesvetailova A, Ed s., e ditors. Gl obal Finance in the New Century: B eyond De regulation. L ondon: Palgrave; 2007. p. 112-25.

Gamson WA. Political Discourse and Collective Action. International Social Movement Research. 1988;1:21944.

Gioia DA, Chittipeddi K. Sen semaking and Sensegiving in Strateg ic Chan ge In itiation. Strateg ic Man agement Journal. 1991;12:433-48.

Goffman E. Fra me Analysis: an Essay on the Organization of the Ex perience. New York: Harper Colophon; 1974.

Goffman E. Felicity's Condition. American Journal of Sociology. 1983;89:1-53.

Greenfield C, Williams P. Financialization, finance rationality and the role of media in Australia. Media Culture Society. 2007;29:415-33.

Hacking I. Mak ing up people. In : Heller TC, Sosn a M, Wellbery DE, ed itors. Recon structing ind ividualism Autonomy, individuality, and the self in western thought. Stanford, CA: Stanford University Press 1986.

Hacking I. Between Michel Foucault and Ervi ng Goffman: between discourse in th e abstract and fa ce-to-face interaction. Economy and Society. 2004;33:277-302.

Harmes A. Mass investment culture. New Left Review. 2001;9:103-24.

Hopwood AG. A ccounting and Ev eryday Lif e: An in troduction. A ccounting, Organizations and So ciety. 1994;19:299-301.

Howe RBK. A social-cognitive theory of desire. Journal for the Theory of Social Behaviour. 1994;24:1-23.

Jeacle, I. Accounting and everyday life: towards a cultural context for accounting research. Qualitative Research in Management \& Accounting. 2009;6:120-36

Jeacle I. Call for pa pers: Accounting a nd Popular C ulture. Special Issue of Accounting, Auditing and Accountability Journal". Accounting, Auditing and Accountability Journal 2010;23(3).

Johed G. Accounting, Stock Markets and Everyday Life [Doctoral Thesis]. Uppsala: Uppsala University; 2007.

Kirk K, Mouritsen J. Spaces of Accountability: explaining the imposition of managing by accounting. In: Munro R, Mouritsen J, ed itors. Accountability: Power, Ethos \& the Technologies of Managing. London: International Thomson Business Press; 1996. p. 245-60.

Knights D, McLean C. New Labour's Third Way: Self, Citizenship, Education and Personal Finance in the 21st Century. Presented in the 16th St anding C onference in Organisational Sy mbolism, Jul y 2 -5, Guaruja B razil. 1998. 
Kronofogden, Konsumentverket. Överskuldsättning och ekonomiska problem bland ungdomar: En kartläggning av risker. KFM Rapport 2008:3. 2008.

Kurunmäki L. A hy brid profession--the acquisiti on of $m$ anagement accounting expe rtise by medical professionals. Accounting, Organizations and Society. 2004;29:327-47.

Kuypers JA. Bush's War: Media Bias a nd Justifications for War in a Terrorist Ag e Lanham, Md: Rowman \& Littlefield Publishers; 2006.

Langley P. Uncertain subjects of anglo-american financialization. Cultural Critique. 2007;65:67-91.

Langley P. Th e Every day Li fe of Global F inance: Sa ving and B orrowing in A nglo-America. Ox ford: Ox ford University Press; 2008.

Latour B. Powers of associations. In: Law J, ed itor. Power, Action and Belief A New Sociology of Knowledge. London: Routledge and Kegan Paul; 1986.

Llewellyn S, Walker SP. Household acc ounting as an interface activity: the hom e, the ec onomy and gender. Critical Perspectives on Accounting. 2000;11:447-78.

Lundberg U . J uvelen i kr onan: Soci aldemokraterna och den al lmänna pensionen. St ockholm: Hjal marson \& Högberg; 2003.

Martin R. The Financialization of Daily Life. Philadelphia: Temple University Press; 2002.

Meyer J W. I deas in M odern O rganizational En vironment. In: C zarniawska B, Se vón G, e ditors. Translating Organizational Change. Berlin: Walter de Gruyter; 1996.

Miller P. Accounting and Objectivity: The Invention of Calculating Selves and Calculable Spaces. In: Megill A, editor. Rethinking Objectivity. London: Duke University Press; 1994.

Miller P. Govern ing by Numbers: Why Calculative Practices Matter. So cial Research: New Sch ool for So cial Research; 2001. p. 379-96.

Miller P. Ma nagement Acco unting and So ciology. In: Ch apman CS, Hop wood AG, Sh ields MD, ed itors. Handbook of Management Accounting Research: Elsevier Ltd; 2007.

Miller P, O'Leary T. Accounting and the construction of the governable person. Accounting, Organizations and Society. 1987;12:235-65.

Miller P, O'Leary T. Making accountancy practical. Accounting, Organizations and Society. 1990;15:479-98.

Miller P, Rose N. Governing Economic Life. Economy and Society. 1990;19:1-31.

Munro R. Just when you thought it safe to enter the water: Accountability, language games and multiple control technologies. Accounting, Management and Information Technologies. 1993;3:249-71.

Odell M. Statement during a visit at the Arlanda gymnasium. Stockholm: Swedish Ministry of Finance, 21 May 2008, http://www.sweden.gov.se/sb/d/1468; 2008.

OECD. Improving Financial Literacy: Analysis of Issues and Policies. 2005.

OECD. The Importance of Financial Education. OECD Policy Brief, July. 2006.

OECD. Improving Financial Education and Awareness on Insurance and Private Pension. 2008.

OECD. The OECD Project on Financial Eduation. 2009.

Ohlsson, C . F olkets f onder. En t extvetenskaplig st udie av det sve nska pe nsionssparandets d omesticering. [Dissertation] Göteborgs universitet, 2007. 
Plånboken. Radio programme broadcasted 15 September. National Swedish Radio, SR; 2008.

Power M. Aft er calculation? Reflectio ns o n Critique of Eco nomic R eason by Andre Gorz". Accounting, Organizations and Society. 1992;17:477-500.

Preda A. T he Rise of the Popular Investor: Financial Knowledge and Investing in England and France, 1840 1880. The Sociological Quarterly. 2001;42:205-32.

Prospera Research. Allmänhetens förtroende för finansbranschen - 2007. 2007.

Rein M, Laws D. C ontroversy, Reframing and Reflection. Paper p resented at a conf erence on Theory, Policy and Society. University of Leiden, The Netherlands, 22 June 1999.

Remund DL. Financial Literacy Explicated: The Case for a Clearer Definition in a n Inc reasingly Complex Economy. Journal of Consumer Affairs. 2010;44:276-95.

Roberts J, Scapens R. Accounting systems and systems of accounta bility -- understanding accounting practices in their organisational contexts. Accounting, Organizations and Society. 1985;10:443-56.

Rose N. Powers of Freedom: Reframing political thought. Cambridge: Cambridge University Press; 1999.

Røvik K A. The Secret s of the Winners: Management I deas that Fl ow. In: Sa hlin-Andersson K, Engwall L, editors. The expansion of management knowledge: carriers, flows, and so urces. St anford: St anford University Press; 2002.

Sahlin-Andersson K , E ngwall L. The e xpansion of m anagement k nowledge: ca rriers, flows, a nd s ources. Stanford: Stanford University Press; 2002.

Schön DA. Gen erative Metap hor: a p erspective on p roblem-setting in so cial p olicy. In : Orton y A, ed itor. Metaphor and Thought. Cambridge: Cambridge University Press; 1979.

Schön DA, Rein M. Fram e Reflection. Toward the Reso lution of In tractable Policy Controversies. New York : Basic Books; 1994.

Sinclair A. The cham eleon of accounta bility: Form s and discourses. Ac counting, Organizations a nd Society. 1995;20:219-37.

Skærbæk P, Tryggestad K. The role of accounting de vices in pe rforming corpora te strategy. Accounting, Organizations and Society. 2010;35:108-24.

Snow DA, B enford R D. I deology, Frame R esonance, and P articipation M obilization. I nternational Soci al Movement Research 1988;1:197-218.

Snow D A, R ochford EB, Jr., Worden SK, Benford RD. Frame Al ignment P rocesses, Micromobilization, and Movement Participation. American Sociological Review. 1986;51:464-81.

Svenska Dagbladet. Öka svenskarnas finanskunskap, published 24 June. Svenska Dagbladet 2008.

Sydsvenska Dagbladet. Article published 23 November. Sydsvenska Dagbladet 2007.

Tversky A, Kahneman D. The Framing of Decisions and the Psychology of Choice. Science. 1981;211:453-8.

U.S. Department of the Trea sury FLEC. Taking Ownership of the Future: the National Strategy for Financial Literacy. 2006.

Walker SP. Professionalisation or i ncarceration? Household eng ineering, accoun ting and th e do mestic id eal. Accounting, Organizations and Society. 2003;28:743-72.

van Gorp B. The Implementation of Asylum Policy: Which Frame Dominates the Debate? Paper presented at the European Consortium for Political Research, 29th Joint Session, Grenoble, France, 6-11 April 2001. 
Williams T. Em powerment of Whom and for What? Fin ancial Literacy Edu cation and the New Regu lation of Consumer Financial Services. Law \& Policy. 2007;29:226-56.

Vollmer H. How to do m ore wi th numbers: El ementary st akes, framing, k eying, an d the three-dimensional character of numerical signs. Accounting, Organizations and Society. 2007;32:577-600.

\section{Websites}

Australia, Financial Literacy Foundation,

http:/www.understandingmoney.gov.au/Content/Consumer/About/aboutflf.aspx (accessed November 2010)

Australia, Understanding Money, http://www.understandingmoney.gov.au/ (accessed November 2010)

Canada, Task Force on Financial Literacy, http://www.financialliteracyincanada.com (accessed November 2010)

EU, Dolceta Online Consumer Education, http://www.dolceta.eu/ (accessed November 2010)

OECD, International Gateway for Financial Education, http://www.financial-education.org (accessed November 2010)

USA, Jump\$tart Coalition for Financial Literacy, http://www.jumpstart.org/ (accessed November 2010) 